\title{
ANKOS and Its Dealings with Vendors
}

\section{Phyllis L. Erdogan \& Bulent Karasozen}

To cite this article: Phyllis L. Erdogan \& Bulent Karasozen (2006) ANKOS and Its Dealings with Vendors, Journal of Library Administration, 44:3-4, 69-83, DOI: 10.1300/J111v44n03 07

To link to this article: https://doi.org/10.1300/J111v44n03_07

曲 Published online: 12 Oct 2008.

6 Submit your article to this journal $\pi$

Щ Article views: 35

4 Citing articles: 2 View citing articles 준 


\title{
ANKOS and Its Dealings with Vendors
}

\author{
Phyllis L. Erdogan \\ Bulent Karasozen
}

\begin{abstract}
SUMMARY. The Anatolian University Libraries Consortium (ANKOS) was formally created in 2001 following joint licensing projects by four libraries in 1999 and twelve in 2000. The consortium has grown to encompass eighty-nine libraries in 2005 , and the number of its contracts has increased to twenty-five. Members include Turkish university libraries and research libraries attached to hospitals and government offices. A voluntary association, ANKOS is run by a Steering Committee composed of the directors of nine member libraries with the help of staff members from those libraries. The first agreements were for print+e-access for journals and for an aggregator database, and these were mostly informal subscription arrangements. An early activity was the development of a model Turkish National Site License. That license now forms the basis for negotiations with vendors, which culminate in formal license agreements. Beginning in 2004, ANKOS contracts are for electronic-only access and are often for multiple years. [Article copies available for a fee from The Haworth Document Delivery Service: 1-800-HAWORTH. E-mail address: $<$ docdelivery@haworthpress.com> Website: <http://www.HaworthPress.com> (C) 2006 by The Haworth Press, Inc. All rights reserved.]
\end{abstract}

Phyllis L. Erdogan is Vice President, Bilkent University, 06800 Ankara, Turkey (E-mail: librdirector@bilkent.edu.tr). She was formerly a member of the ANKOS Steering Committee and Library Director, Bilkent University, 06800 Ankara, Turkey.

Bulent Karasozen is ANKOS Chairman and Library Director, Middle East Technical University, 06531 Ankara, Turkey (E-mail: bulent@ metu.edu.tr).

[Haworth co-indexing entry note]: "ANKOS and Its Dealings with Vendors." Erdogan, Phyllis L., and Bulent Karasozen. Co-published simultaneously in Journal of Library Administration (The Haworth Information Press, an imprint of The Haworth Press, Inc.) Vol. 44, No. 3/4, 2006, pp. 69-83; and: Library/Vendor Relationships (ed: Sam Brooks, and David H. Carlson) The Haworth Information Press, an imprint of The Haworth Press, Inc., 2006, pp. 69-83. Single or multiple copies of this article are available for a fee from The Haworth Document Delivery Service [1-800-HAWORTH, 9:00 a.m. - 5:00 p.m. (EST). E-mail address: docdelivery@haworthpress.com].

Available online at http://www.haworthpress.com/web/JLA

(C) 2006 by The Haworth Press, Inc. All rights reserved. doi:10.1300/J111v44n03_07 
KEYWORDS. ANKOS, consortia, consortium, pricing models, cost distribution, database licensing, multi-year contracts, price negotiations, library/vendor relations, Turkey, international

\section{INTRODUCTION}

The Turkish academic library community entered a new era with the creation in May 2001 of the Anatolian University Libraries Consortium. Known by its Turkish acronym, ANKOS, the consortium's development has been documented in an article written by two members of its steering committee. ${ }^{1}$ In that article is to be found a complete list of licensed databases since the first ANKOS contracts in 2002, including those signed for 2004. The present article will bring the reader up to date on ANKOS work for 2005.

\section{BACKGROUND}

In 1946, the year that the National Library was established, there were three Turkish universities; by 1981 their number had risen to nineteen. In that year, a revision of the Turkish law governing institutions of higher education brought all post-secondary education into the university system, provided for an increase in the number of state universities, and following a change in the Turkish Constitution, permitted private higher education on the condition that such institutions be non-profit and that their students be admitted according to the national policy of numerus clausus whereby all candidates to enter higher education are subject to a central entrance examination and placed in a specific university department according to the results. Since the passage of that law, twenty-four universities and two vocational schools at post-secondary level have been opened by private foundations. Another thirty-one universities and two institutes of technology have been opened by the State. These, together with the nineteen institutions dating from prior to 1981, two international universities located in Kyrgyzstan and Kazakhstan operated jointly by their own and Turkish authorities, three military academies, and five universities in the Turkish Republic of Northern Cyprus, are all potential members of ANKOS. Membership is also open, subject to case-by-case decisions, to special (research) libraries. Participation in at least one ANKOS agreement with a product supplier constitutes membership in ANKOS. 
Of the fifty-nine institutions created following the 1981 law, the state universities were often located outside the large metropolitan areas and were without library collections or technological infrastructures. Not surprisingly, they found it difficult to attract teaching staff and students. Thus, when the National Academic Network and Information Center (ULAKBIM) was close to completing its mission of providing all universities with Internet connections, it was time for ANKOS in 2002 to undertake to arrange licenses to provide access to electronic resources for as many institutions as possible.

Given the extreme diversity of conditions of the universities, this has been a challenge. For example, ANKOS member institutions' budgets for collection expenditures (books, periodicals, other non-book items, and electronic resources) in 2004 varied between $\$ 100,000$ and $\$ 3,000,000 .^{2}$ Enrollments vary from fewer than 100 to over 50,000. ${ }^{3}$ English language knowledge of staff and students ranges from almost none (no English preparatory classes and no instruction in English) to institutions where the medium of instruction is English. ${ }^{4}$ All these institutions need to use resources, but to what extent can they afford them, and how effectively can they be used and by how many users? These are problems for ANKOS as well as for the libraries in other southern European countries, which greatly affect negotiations with publishers and vendors. It was in recognition of this communality of problems less frequently encountered in some other countries, that consortia from Greece, Italy, Portugal, Spain, and Turkey banded together to form SELL, the Southern European Libraries Link, ${ }^{5}$ to discuss mutual problems and approaches to vendors.

Added to the problems posed by the range of institutions is the dearth of knowledge of English among librarians and the lack of experience of librarians in negotiating contracts and prices. Certain firms with which ANKOS has contracts have Turkish agents, which facilitates communications with the members but does not always lead to easier contract negotiations since it means an extra layer to pass through.

\section{GROWTH OF ANKOS}

Since its establishment in 2002, ANKOS has grown rapidly both in terms of member libraries and total number of database subscriptions. In the first year, ANKOS members had a total of 235 database subscriptions through the consortium. This number increased to 402 in 2003 and 564 in 2004. It is expected that there will be a total of 729 subscriptions 
for 2005 when all details are finalized for the deals for twenty-five databases. Twelve of these are from commercial publishers, nine from society publishers, three are aggregator databases, and one is a database of electronic books. The average number of ANKOS contracts per member library increased from 5.4 in 2003 to 7.2 in 2004 and 8.6 in 2005. This data shows that despite insufficient financial resources, Turkish academic and research libraries are still trying to enrich their electronic collections and that saturation level has not yet been reached. This can be explained in part by the establishment of new universities (the Government has announced that fifteen more will be chartered in 2005). At the same time, probably both as a result of the ANKOS-aided increased access to research publications and funding from the European Union and other foreign sources, the number of research publications emanating from Turkey increased by an average of 25 percent annually between 2002 and 2004. For the first time the Turkish Scientific and Technical Research Council (TUBITAK) has also announced significant financial support for research, in the amount of US $\$ 400,000$ for 2005.

Usage statistics for the ANKOS full-text databases have monitored rapid growth: from a total number of full-text downloads of 2,300,000 in 2002 to $6,020,000$ in 2003, and to 8,470,000 in 2004. Only eleven of the ANKOS databases were COUNTER-compliant in 2004, and ACS, Emerald, and Taylor \& Francis were first licensed by ANKOS in 2004 so it is not possible to compare usage statistics for those databases with earlier years. Among the COUNTER-compliant databases, Oxford University Press e-journal usage increased by 56 percent from 2003 to 2004, with 169,000 full-text downloads. Similar increases were observed for ScienceDirect (41 percent increase to 4,600,000 full-text downloads in 2004) and Blackwell Synergy (30 percent increase, to 383,000 downloads). The increase in usage of aggregator databases was low: ProQuest databases with 491,000 and EBSCOhost with 795,000 full-text downloads in 2004 showed increases of about 6 percent and 10 percent, respectively.

To foster awareness and use of the databases, ANKOS arranges several education seminars per year in different areas of the country. In 2004, user education was given for EBSCOhost, Elsevier Science Direct, IEEE/IEE Electronic Library (IEL), Kluwer Online Journals (now part of Springer), ProQuest, Web of Science, and Wiley InterScience.

To overcome the lack of sufficient English of both librarians and users, ANKOS has collaborated with vendors to translate database brochures into Turkish and distribute them to the member libraries. The 
first three such Turkish publications were for the American Chemical Society, Elsevier Science Direct, and Web of Science. Some of the vendors, for example ProQuest and the Institute of Physics, also make Turkish interfaces available on their web sites. In 2005, ANKOS will concentrate more on evaluating usage statistics and user education, especially during the annual meeting to which vendors come to introduce their products.

\section{THE ANKOS MODUS OPERANDI}

ANKOS is a voluntary association of academic libraries, together with a few research and special libraries, which operates through the efforts of the nine heads of libraries who form its Steering Committee. The Steering Committee members are in turn assisted by members of their staffs who serve as "ANKOS liaisons" for each product or vendor with whom negotiations are undertaken. A visit to the ANKOS English-language web site ${ }^{6}$ will provide information about this structure and other details.

Proposals of products come to the Steering Committee from members and vendors. If the Steering Committee finds a product worthy of consideration by ANKOS, one of the Committee members is requested to appoint a liaison librarian to arrange for a trial, announce the trial to the ANKOS membership, receive usage statistics from the vendor at the end of the trial, and collect information about the members' desires to subscribe to the product. If there is sufficient interest, the liaison person then ensures that the vendor is aware of the ANKOS licensing principles and the Turkish National Site License (TRNSL). ${ }^{7}$ The TRNSL is a model license which was developed by the ANKOS "Licensing Working Group" composed at that time of two library directors and an American legal librarian who was working in one of the ANKOS member libraries. The text of the TRNSL was drawn up following a review of many model consortial licenses, with the addition of requirements specific to the Turkish situation such as the necessity of individual invoices and vendor support for user education with Turkish-language materials. Both the principles and the TRNSL can be consulted on the ANKOS web site. Negotiation of the contract is conducted by the Licensing Working Group together with a member of the Steering Committee.

At the same time that the text of the contract is taking shape, pricing is negotiated. Until now, price negotiations have been carried out in some cases by the liaison librarian and sometimes by a member of the 
Steering Committee. At a recent Steering Committee meeting, however, it was proposed that the role of the Licensing Working Group should gradually be expanded to include price negotiations, because it was recognized that this is also an area requiring an accumulation of experience and the development of expertise.

\section{TRIALING OF DATABASES}

Trials of subscribed and proposed databases play an important role in the ANKOS selection process and decisions about continuation of contracts, and they are a preferred practice by vendors and libraries. ANKOS is offered some twenty trials a year by publishers. At the end of each trial, the usage statistics are collected by the ANKOS liaison, who also collects the reactions of the trialing libraries. For 2005, as a result of the trials in 2004, ANKOS made new agreements with SIAM (ten members), JSTOR (ten new members so far in addition to previously subscribed libraries), and Serials Solutions (eleven members). Trials also led to the enlargement of existing consortial agreements: the number of OVID members rose from fifteen to twenty-seven; Taylor \& Francis from seventeen to thirty-five; Blackwell Synergy from twenty-six to thirty-seven; and MathSciNet from fifteen to twentythree. Trials with ALPSP (Association of Learned Professional Society Publishers), BMJ (British Medical Association Journals), CSA (Cambridge Scientific Abstracts), CAB Abstracts, Economist Intelligence Unit, GeoRef, ISI Emerging Markets, Safari, Sage, and the World Bank did not result in contracts, either due to prices that the members could not afford or low usage. In a few cases there were disagreements about the licensing terms. Although there were several attempts at systematic downloading and robot usage during the trials, ANKOS was able to stop such misuse before it endangered the consortium as a whole. (The infrequent examples of such illegal use by subscriber institutions' users have been promptly dealt with also to the satisfaction of the vendors.)

\section{EXPERIENCES WITH VENDORS}

ANKOS licenses in 2004 were with journal publishers (e.g., Cambridge University Press, Elsevier), aggregators such as EBSCO Publishing and ProQuest, indexing services (including MathSciNet and the ISI Web of Science), and e-book suppliers. Some of these products had 
originally been subscribed to jointly by the libraries which subsequently formed ANKOS, and at the beginning, the subscriptions continued without the benefit of a license for the consortium. As the years pass, and with the help of the model Turkish National Site License, these relationships are gradually being formalized, which we believe is to the benefit of both parties. During these years, our contacts with vendors have shown us that while ANKOS may not be a sophisticated negotiator, in this new library world neither are a number of the firms we deal with. All of us are groping for the best way to proceed, and mutual goodwill and an open line of communication are the most important factors in reaching results that are mutually satisfactory.

Multi-year contracts provide a means for consortia to guarantee a price cap over the period of the contract. With ANKOS affairs being handled by a group of volunteers who all have full-time library jobs, three-year contracts are looked upon also as a way to decrease the workload of the liaison librarians, the Licensing Working Group, and the Steering Committee. By staggering starting dates there will eventually be fewer contracts to negotiate per year. The contracts are designed to allow new members to join after the first year, with all member contracts ending together when the original contract term is ended. The Licensing Working Group is also careful to include in the agreements a clause whereby the supplier guarantees not to rescind the contracts of all ANKOS members for the breach of contract of any single library, with a view especially to protecting the consortium against non-payment by an individual member.

As mentioned previously, ANKOS is a voluntary association, and despite a great deal of consideration and consultation, no means has been found to establish a legal bond between the members. In practical terms this means that each member institution signs a license for each product. It also means that ANKOS cannot collect funds from the members in order to pay a single consortium invoice, which would undoubtedly bring financial advantages apart from the fact that some vendors have refused to consider a deal which required individual invoices for the members.

According to Turkish law, the state universities have to spend their budgets for services received within the year; they cannot pay license fees for the next year. Also, the budgets of the state universities are opened during the year in installments, and the first funds are made available in April. Sometimes library funds are withheld or diverted by the university administration to other uses. These are among the situations which ANKOS must arrange with the vendors, and the solution to 
this one is often to employ an intermediary willing to pay the vendor on time and collect from the libraries later, charging a commission. This solution is favored by many vendors who, it should be recognized, have been very patient with delayed payments. We hope that the payment issues will be resolved by the expected change in regulations which will allow universities to move to a multi-year budgeting system.

A modification in ANKOS contracts since 2004 has been the decision to license only electronic access to the sources. This leaves the print subscriptions to be sorted out by the individual members who wish to continue receiving them. This decision was taken in connection with ANKOS' desire to base fees not on each member's previous individual print holdings but on the overall consortial holdings and total fees paid previously by the members, with the total ANKOS fee to be divided up by ANKOS among the members. It was also a result of the difficulties encountered subsequent to the passing of a new tender law affecting state universities, which requires that the universities call for competing bids by several vendors for the supply of print subscriptions. Where there is only one possible supplier, the law requires that state universities present a document guaranteeing that the supplier has the exclusive right to market the product in Turkey and an Embassy document ("Apostille") certifying the guarantee.

\section{PRICING NEGOTIATIONS AND FEE DISTRIBUTION}

Cost division models are new for many consortia, and we want to mention three which have been presented at E-ICOLC meetings. The Swedish consortium BIBSAM and the Finnish consortium FinELib ${ }^{8}$ have models similar to each other in that they are both based on FTEs and prior fees or, if usage statistics are available, they may be used to identify user groups and their populations. FinELib uses the same cost division model for all databases subscribed to by the consortium, whereas BIBSAM has several models, taking into account the size of the potential user group. Both groups acknowledge that fee distribution is an ongoing process that needs to be transparent so that member libraries feel that it is fair. In this connection they have both found it useful to limit the range of costs to members by setting maximum and minimum fees. As will be seen below, both models have similarities with models applied by ANKOS, although in ANKOS there has not been a conscious setting of upper and lower limits to prices. The BIBSAM and FinELib use of FTE is also different, in that students and teachers/researchers are 
weighted differently and according to field of study, whereas in the ANKOS case this was done only for the IEEE agreement.

Another cost division model, applied by the Consortium of Academic Libraries of Catalonia, was discussed at length by Lluis Anglada and Nuria Comellas in their 2002 article. ${ }^{9}$ This model is based on "dimensions or characteristics" of the institutions and the cost of their print holdings. Anglada and Comellas emphasize the difference in teaching between universities in the USA, UK, and northern Europe and those in the southern European countries, where the traditional method of large classes and lecture notes is also the case for the majority of Turkish universities. They also criticize the definition of FTE as used in the English-speaking countries because education authorities in many European countries do not record their student data in terms of FTE. On this subject, however, Turkey is similar to the English-speaking countries, since there is a time limit for completion of studies and detailed statistics on researchers and students according to level and department are available from the Council of Higher Education. ${ }^{10}$

Pricing is an aspect of the ANKOS agreements which requires time, innovative thinking, and patience. Most, if not all, early ANKOS contracts for electronic access were based on print subscriptions held by the ANKOS members. In the first years this seemed an obvious and even fair approach. As pointed out earlier, however, many Turkish universities, especially the newest ones, have no or very few print subscriptions, and the pricing schemes of the publishers were allowing them access at a tiny fraction of the amounts paid by older members. Initially this situation was accepted by the larger or better funded libraries as a way to bring resources to the less fortunate institutions. As the years passed and the better-off libraries were supporting an ever increasing number of members at higher and higher percentages of the costs, the Steering Committee undertook to convince the vendors to agree to a total price for the consortium and leave the distribution to ANKOS. This has been accomplished with several three-year contracts, both with aggregators and journal publishers, although with expressions of concern from the libraries whose yearly subscription rates increased more than they had expected.

The first publisher with whom ANKOS signed an agreement which included an ANKOS-dictated fee structure was the Thomson Company for Web of Science (WOS). All ANKOS/WOS members subscribe to two indexes (in all but one case Science Citation Index and Social Sciences Citation Index) and may choose to subscribe also to the third. Member libraries were grouped by ANKOS into four "tiers" according 
to a formula which gave points to each library for the number of its full-time equivalent (FTE) four-year undergraduate students, postgraduate students, and teaching staff; 11 its collection budget; and the degree to which English is taught and/or used for instruction in the institution since all ANKOS contracts are, so far, for English-language materials.

The first three-year Thomson contract which used the ANKOS tiering system ended on December 31, 2004. For the new three-year contract certain changes were made by ANKOS in the membership of the pricing tiers, taking into account the amount of use made by the members of the database agreement (use per FTE). In these calculations, FTE, budget, and use/FTE were weighted equally and extent of English use was given a lesser weight. Another modification was the addition of a fifth tier, which allows disadvantaged institutions to join at a greatly reduced fee. Tier 1 members pay the highest amount with the new Tier 5 paying 22 percent of the amount paid by Tier 1 . An auxiliary benefit to ANKOS members, although not reflected in the current license agreement, is a favorable price for back years, again based on the ANKOS tiers. The 2005-2007 agreement has been accepted by fifty-nine libraries.

Another publisher with whom ANKOS has a tier arrangement is IEEE. A first abortive attempt at forming an ANKOS/IEEE consortium for 2003 was followed by more successful negotiations for 2004, whereby twenty-two ANKOS members had access to the IEL. That agreement was for one year, and the ANKOS libraries that joined were grouped according to FTE figures for the respective university's departments of electrical and electronics engineering, computer engineering, physics, physics engineering, and biomedical engineering, as follows: the number of undergraduate students was multiplied by a factor ranging from 0.1 to 1 assigned to the institution according to the amount of English instruction there. (Institutions where teaching is entirely in English were assigned the factor 1.) To that number was added the total of postgraduate students and teaching staff multiplied by 3 . The universities were then divided into three groups according to their total FTE as calculated, so that the institutions with FTE $>1,399$ were assigned to Group 1, $\mathrm{FTE}=800-1,399$ to Group 2, and FTE $<800$ to Group 3. Group 1 libraries paid the highest amount, Group 2 paid 25 percent less, and Group 3 paid 50 percent less for the IEL database. In addition, TUBITAK paid a special price for access by its various installations across Turkey. Although it was originally ANKOS' intention that the new contract be for 2005-2007, this was not realized. For the year 2005 there were twentyfive members, grouped in the same manner as for 2004, with the same percentage price increase for each group. 
Although ANKOS members have had subscriptions to EBSCOhost databases for a number of years at ANKOS negotiated prices, 2005 marks the first time a formal license agreement had been drawn up. Members were divided into groups paying different amounts for the same databases and a multi-year contract has been signed with yearly price increases agreed upon. There was a moderately successful attempt to make ANKOS subscriptions more uniform (i.e., to have all members subscribe to the Premier version at a favorable price rather than some to the Elite version). This was accomplished only for Business Source Premier.

In 2005, the ANKOS Steering Committee members involved in contract negotiations experienced difficulties due to the lack of experience of some member libraries' directors. Not realizing the importance of confidentiality, certain details were made available more widely than should have been the case, which set off a fierce competition between vendors' local representatives in an attempt to wrest ANKOS members from each other. From the eventual decisions of the ANKOS members, however, favoring one product over another appears to be more a matter of habit than anything objective since although there were many subscriptions dropped from and added to each, only one library appears to have dropped one of these products in favor of the other.

During the past year, one publisher which has been the subject of much discussion and controversy in the international library community is Elsevier, and ANKOS was not an exception in finding the early negotiations difficult. ANKOS members have had agreements with Elsevier for Science Direct (including Academic Press, since there had already been an ANKOS agreement for those journals before the publisher was taken over by Elsevier) since 2001, when a one-year contract was signed. That was followed by a three-year contract which ended on December 31, 2004. The earlier contracts were based on each member's prior print subscriptions, with an added value for cross-access to all Science Direct subscriptions whether subscribed to by an ANKOS member or not.

For the new contract Elsevier presented ANKOS with an extremely complicated formula by which it charged members according to prior print holdings or lack of them with several add-on fees, which resulted in an unacceptably large increase over the 2004 fee. ANKOS presented a counter-offer which, although based on the 2004 "total spend," brought about some important changes in addition to reducing the price significantly. Based on prior print holdings, it was pointed out that seven members of the sixty-two were paying 64.5 percent of the total 
ANKOS fee paid to Elsevier. This meant that their fee per use of the database was much higher than the average of the other fifty-five members. After examining the fee distribution details, the ANKOS Steering Committee decided to reduce the seven members' share of the total to 54 percent and distribute the difference among the other fifty-five members. The fee for accessing ANKOS non-subscribed titles was split equally between all sixty-two members. Fifty-eight of the former sixty-two members accepted the new contract and four new members signed on. Because the new contract could not be finalized by the end of 2004, an interim short-term agreement was signed to allow time to complete the negotiations for the three-year license agreement.

Kluwer Academic, and its new owner Springer, had also been ANKOS vendors with their respective one-year contracts ending December 31, 2004. Despite the fact that their merger had been announced a year ahead, and an early request from ANKOS for a merged three-year renewal contract, the new Springer was unable to propose such a contract until early December. Due to the unacceptability of its terms, ANKOS chose to make a one-year contract in the hope that a more reasonable agreement could be achieved during 2005 for later years.

Other contracts have also been renewed for 2005 (ACM, Blackwell Synergy, Bowker, ebrary, Emerald, Gale, MathSciNet, Ovid, Oxford University Press, Taylor \& Francis, Wiley InterScience). Some of these are straightforward and some less so and will be the object of intensified efforts by ANKOS for more favorable conditions in subsequent years as negotiators have more time available from not having to renew every contract each year.

\section{REFLECTIONS ON OUR EXPERIENCES}

In the four years of working with the consortium, we have acquired knowledge in negotiation and licensing as well as greater awareness of the emerging digital environment for libraries and issues of scholarly communication. The process of selection and licensing of electronic collections is now fairly well defined. Negotiations and licensing are still carried out by a small number of librarians, but we plan to enlarge this working group. Similarly, more librarians need to be involved in user education and evaluation of usage statistics. In this connection we are planning to invite foreign experts to give training workshops for ANKOS member libraries. 
Due to the diversity of the libraries, from time to time there has been a communications overload in dealing with access and payment problems of the members. At the beginning, there was little understanding among librarians of the importance of consortial work and the rapidly changing information environment. In time, however, every academic library has acquired one or more of the electronic collections licensed via ANKOS. Besides the many new libraries which were born in the digital age and therefore have predominantly electronic collections, many other libraries are moving to e-only subscriptions; of the sixty-two members of ScienceDirect, only eight libraries continue to have print subscriptions.

Although library budgets are better than they were four years ago, many libraries have funds that are disproportionate to the size of their institution. Another factor which complicates the licensing process is the direct involvement of university administrators in decisions for the libraries, which causes an additional workload for ANKOS.

Since ANKOS became a member of SPARC Europe, scholarly communication and open access have been discussed more intensively in Turkey. On its agenda for the future, ANKOS plans to give attention to stimulating institutional repositories, management of electronic resources, and supporting research and reference work.

\section{CONCLUSION}

ANKOS has gained valuable experience which has helped to shape its expectations from and approach to working with vendors. As the number of members and vendor contracts grew, the importance of having a clear and comprehensive license agreement became more obvious. Thus, while ANKOS is managed and operated by volunteer library directors and their staffs, a few of those volunteers have the ongoing responsibility of negotiating contracts. They have attempted to reduce this workload over time by preferring three-year agreements when possible and advantageous.

Fee distribution is another subject which has gained importance with the expansion of the consortium. Whereas the fee distribution in early contracts was dictated by the vendors, more recently ANKOS has agreed on a global figure with distribution of the costs being the province of the consortium. At this point in time, ANKOS has five main types of contractual arrangements: (1) "e-only plus consortium fee"; (2) "print plus consortium fee"; (3) "population (FTE)-based"; (4) "scaled" (price decreases depend on increase in number of members); and (5) "ANKOS- 
imposed groupings" by FTE, collection budget, level of English and usage. Only one vendor applies a fixed fee for all institutions within the consortium.

Only three vendors have been dropped by ANKOS. Ten ANKOS members subscribed to Safari E-books in 2003. Because of the limitation on concurrent users and complications with swapping book titles, the database was not used efficiently and ANKOS decided not to continue with it for 2004. In late 2004 the vendor offered a new trial and relaxed the concurrent user restrictions a little, but this time there was not sufficient interest among the institutions to reach an agreement. ANKOS had included E-Village in its subscription list in 2002. Originally this database was subscribed to by a group of universities with the same fixed price for each institution. Despite our warnings, the vendor arranged three-year contracts with libraries ending in different years. From 2002-2004 we observed big differences in the usage by member institutions, and we proposed that the vendor take the size and usage of the institutions into account and work out a differential pricing. Due to the vendor's resistance to changing its practices and pricing policy, ANKOS decided not to have a contract with E-Village for 2005. ANKOS had an agreement for 2002 with Micromedex, but it was not renewed due to insufficient interest.

While early contracts covered print and electronic versions of journals, as of 2004 ANKOS has left print subscriptions to the individual libraries to handle while the consortium makes agreements only for e-access. It is to be hoped that a means will eventually be found to give ANKOS legal status, to enable it to obtain external funding, and to allow ANKOS to collect fees from its members in order to deal with the vendors as a single customer.

Library users and librarians realize that the consortium has achieved access to resources undreamed of in Turkish academe just four years ago. It is the hope of the ANKOS librarians that this will be acknowledged in a way that will lead to its permanence as an institution.

\section{NOTES}

1. Bulent Karasozen and J. A. Lindley. "The Impact of ANKOS: Consortium Development in Turkey," Journal of Academic Librarianship 30 (2004): 402-409.

2. Official Gazette 28 December 2003 (supplement, no. 25330) and personal communications of the directors of the private universities. 
3. Council of Higher Education webpage. Date last accessed: 14 January 2005. (http://www.yok.gov.tr/istatistikler/istatistikler.htm). Personal communications of library directors.

4. 2004 ÖSYM Yüksekögretim Programlarl ve Kontenjanları Kılavuzu (Student Selection and Placement Center Guide to Higher Education Programs and Quotas). 2005.

5. (http://www.heal-link.gr/SELL/index.html) Date last accessed: 10 January

6. (http://www.ankos.gen.tr/index.php) Date last accessed: 14 March 2005. The ANKOS web site lists licensing firms and participant institutions with information such as the time periods of the licenses and the ANKOS member libraries in each contract, a description of the ANKOS structure, and a list of member libraries, their directors, contact details, IP ranges and ANKOS liaison librarians.

7. Jane Ann Lindley. "The Turkish National Site License (TRNSL)," Serials 16(2003): 187-190.

8. Kari Stange, Kristiina Hormia-Poutanen, Karin Bergstrom Gronvall, and Eeva Laurila. "Cost division models in BIBSAM and FinELib consortia," Serials 16(2003): 285-292.

9. Lluis Anglada and Nuria Comellas, "What's fair? Pricing models in the electronic era," Library Management 23(2002): 227-233.

10. Council of Higher Education web page. Date last accessed: 14 January 2005. (http://www.yok.gov.tr/istatistikler/istatistikler.htm). Personal communications of library directors.

11. Council of Higher Education web page. Date last accessed: 14 January 2005. (http://www.yok.gov.tr/istatistikler/istatistikler.htm). Personal communications of library directors. 